Laila Fitriani dan Asti Aini

\title{
PENGARUH STRATEGI PEMASARAN TERHADAP MINAT NASABAH MEMILIH PRODUK TABUNGANKU (Studi di Bank Muamalat Indonesia Cabang Serang)
}

\begin{abstract}
Abstrak
Hasil wawancara penulis dengan dengan custumer service Bank Muamalat Indonesia Cabang Serang menyatakan jumlah seluruh nasabah tabunganku dari bulan Mei 2010 sampai Oktober 2013 berjumlah 578 orang. Hal ini menunjukkan kurangnya minat nasabah terhadap program tabunganku yang salah satu penyebabnya adalah tidak efektifnya strategi pemasaran dan posisi kantor yang kurang strategis. Stategi pemasaran pada dasarnya memberikan panduan tentang kegiatan yang akan dijalankan untuk dapat tercapainya tujuan pemasaran suatu pemasaran. Mulai dari pemenuhan produk (product), penetapan harga (price), pengiriman barang (place), dan mempromosikan barang (promotion).

Masalah yang diangkat dalam riste ini adalah: 1. Apa alasan nasabah dalam memilih produk tabunganku? 2. Berapa besar pengaruh strategi pemasaran terhadap minat nasabah memilih produk tabunganku pada Bank Muamalat Indonesia Cabang Serang?

Sampel yang digunakan dalam penelitian ini adalah nasabah yang menggunakan tabunganku di Bank Muamalat Cabang Serang. Jenis data yang digunakan adalah primer dengan menyebar angket/kuesioner kepada nasabah yang menggunakan produk tabunganku. Metode yang digunakan adalah analisis deskriptif, uji t, koefisien korelasi dan koefisien determinasi.

Dari hasil penelitian, terhadap 41 orang responden, penulis menyimpulkan bahwa strategi pemasaran berpengaruh signifikan terhadap minat nasabah memilih produk tabunganku. Dari hasil statistik menggunakan SPSS ver 16.00 hal ini dapat dilihat dari angka korelasi sebesar 57\% yang artinya hubungan kedua variabel adalah sedang. Dari hasil tersebut menunjukkan bahwa $t_{\text {hitung }}$ lebih besar dari $t_{\text {tabel }}$ yaitu sebesar $(4,360>1,70)$. Hal ini berarti bahwa $H_{0}$ ditolak dan $H_{a}$ diterima, artinya bahwa ada pengaruh antara Strategi pemasaran terhadap minat nasabah memilih produk tabunganku. Nilai $R$ sebesar 0.572 yang artinya pengaruh strategi pemasaran terhadap minat nasabah memilih produk tabunganku sedang. Nilai $R^{2}=0,328$ artinya bahwa $32,8 \%$ perubahan tabunganku dipengaruhi oleh strategi pemasaran, dan sisanya $(100 \%-32,8 \%=67,2 \%)$ dipengaruhi oleh variabel lain yang tidak dibahas dalam penelitian ini.
\end{abstract}

Kata Kunci: Pemasaran, nasabah, syariah, tabunganku. 


\section{Pendahuluan}

Ditengah pesatnya persaingan dunia perbankan nasional yang menerapkan sistem bunga, dengan menggunakan sistem ekonomi Islam yang berlandaskan kepada Al-qur'an dan Hadits. Perbankan syariah muncul dan mampu bersaing bahkan kini perkembangannya amatlah pesat. Seperti yang telah diketahui, fungsi dasar dari bank itu adalah mengumpulkan dana dari masyarakat dan menyalurkannya kembali kepada masyarakat yang membutuhkan dana. Selain itu bank juga dapat memberikan jasajasa keuangan dan pembayaran lainnya, dengan tujuan untuk mempermudah segala bentuk transaksi yang dilakukan oleh masyarakat dan sebagai kegiatan penunjang untuk menghimpun dan menyalurkan dana.

Dalam hal ini apabila bank menginginkan produknya mudah untuk dijual dan ekspansif atau dengan kata lain banyak diminati oleh nasabah maupun calon nasabahnya, maka persyaratan dan produknya harus dipermudah. Misalnya kemudahan dalam hal memperoleh produk itu, baik secara persyaratan dokumentasi, transaksi pembayaran maupun prosedur-prosedur lainnya. Dan produk tersebut haruslah dapat menjawab semua kebutuhan masyarakat. Inilah salah satu persoalan yang dihadapi suatu bank dalam menciptakan produk baru. Di satu sisi bank menginginkan suatu alat untuk menjaring nasabah lebih banyak lagi, tetapi disisi lain bank akan dihadapi oleh sebuah dilema teknis yang harus disiasati. Dari setiap produk yang diluncurkan oleh bank, pasti bertujuan untuk menarik minat masyarakat untuk membeli atau mempergunakan produk yang dikeluarkan oleh bank yang bersangkutan.

Kegiatan bank syariah pada dasarnya merupakan perluasan jasa perbankan, bagi masyarakat yang membutuhkan dan menghendaki jasa pembayaran perbankan yang tidak didasari pada sistem bunga yang dianggap riba bagi sebagian besar masyarakat (nasabah) melainkan pembayaran atas dasar prinsip syariah yaitu sistem bagi hasil yang dianggap lebih halal.

Tabunganku adalah tabungan untuk perorangan dengan persyaratan mudah dan ringan yang diterbitkan guna menumbuhkan budaya menabung serta meningkatkan kesejahteraan masyarakat. ${ }^{1}$

Setiap aktivitas dalam mencapai kegiatannya memerlukan strategi. Dari hasil wawancara dengan Custumer Service Bank Muamalat Cabang Serang, jumlah seluruh nasabah tabunganku pada Bank Muamalat Indonesia Cabang Serang dari bulan Mei 2010 sampai Oktober 2013 berjumlah 578 orang, ini berarti minat nasabah kurang kemudian tingkat efektifitas strategi dan tempat menjadikan tabunganku kurang di minati. Stategi pemasaran pada dasarnya adalah rencana yang menyeluruh terpadu dan menyatu di bidang pemasaran, yang memberikan panduan tentang kegiatan yang akan dijalankan untuk dapat tercapainya tujuan pemasaran suatu pemasaran. Mulai dari pemenuhan produk (product), penetapan harga (price), pengiriman barang (place), dan mempromosikan barang (promotion). Bank Muamalat sebagai bank syariah dalam mencapai tujuan dan sasarannya, bank pun melakukan strategi guna menarik minat nasabah memilih produk tabunganku. 


\section{Kajian Teoritis \\ A. Landasan Teori \\ 1. Pengertian Pemasaran}

Pengertian pemasaran atau marketing adalah kegiatan manusia yang diarahkan untuk memenuhi kebutuhan dan keinginan melalui proses pertukaran. Konsep yang paling mendasar dalam pemasaran yaitu kebutuhan manusia, di mana kebutuhan manusia (human need) adalah keadaan seperti perasaan kehilangan dalam diri seseorang. Kebutuhan manusia itu luas dan kompleks yang meliputi kebutuhan dasar, rasa aman, sosial, penghargaan dan aktualisasi diri. Sedangkan keinginan manusia (human want) adalah bentuk yang berasal dari kebutuhan manusia yang dibentuk oleh budaya dan pribadi seseorang.

Tujuan pemasaran adalah membuat agar penjual berlebih-lebihan dan mengetahui serta memahami konsumen dengan baik sehingga produk atau pelayanan cocok dengan konsumen tersebut dan laku dengan sendirinya. Dengan berkembangnya masyarakat maka keinginan anggota masyarakat berkembang pula. Di lain pihak para produsen mempromosikan produknya sebagai sebuah pemuas dari salah satu atau lebih kebutuhan manusia.

\section{Strategi Pemasaran}

Proses dalam pemenuhan kebutuhan dan keinginan manusia inilah yang menjadi konsep pemasaran. Mulai dari pemenuhan produk (product), penetapan harga (price), pengiriman barang (place), dan mempromosikan barang (promotion). Seseorang yang bekerja dibidang pemasaran disebut pemasar. Pemasar ini sebaiknya memiliki pengetahuan dalam konsep dan prinsip pemasaran agar kegiatan pemasaran dapat tercapai sesuai dengan kebutuhan dan keinginan manusia terutama pihak konsumen yang dituju. ${ }^{2}$

Strategi pemasaran pada dasarnya adalah rencana yang menyeluruh, terpadu dan menyatu di bidang pemasaran, yang memberikan panduan tentang kegiatan yang akan dijalankan untuk dapat tercapainya tujuan pemasaran suatu pemasaran. ${ }^{3}$

\section{Pemasaran Dalam Islam}

Semua aktivitas kehidupan perlu dilakukan berdasarkan perencanaan yang baik. Islam agama yang memberikan sintesis dan rencana yang dapat direalisasikan melalui rangsangan dan bimbingan. Meski belum diperoleh bukti adanya sesuatu pembahasan sistematik tentang masalah tersebut, namun berbagai perintah dalam AlQuran dan Sunnah menegaskannya. Dalam Al-Quran tercantum: QS. Al-Jumu'ah: 10, yang artinya, 


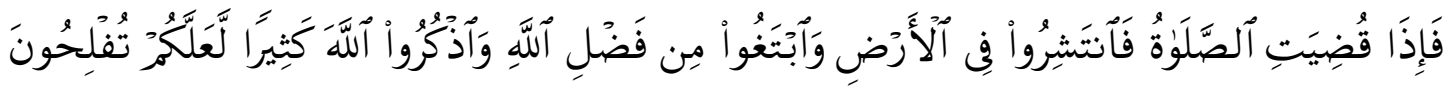

"Apabila telah ditunaikan sembahyang maka bertebaranlah kamu di muka bumi, dan carilah karunia Allah dan ingatlah Allah banyak-banyak supaya kamu beruntung. ",

Berdasarkan ayat ini dapat dijelaskan makna dalam kata "carilah karunia Allah" yang digunakan di dalamnya dimaksudkan untuk segala usaha halal yang melibatkan orang untuk memenuhi kebutuhannya.

Di samping itu, pelaksanaan rencana pemasaran dalam Islam, kita tergantung pada prinsip syarikat (kerjasama) yang telah diakui secara universal. Hal ini berarti pelaksanaan perencanaan dilaksanakan melalui partisipasi sektor pemerintah dan swasta atas dasar kemitraan. Yakni terlaksana melalui prinsip abadi mudharabah, yakni tenaga kerja dan pemilik modal dapat disatukan sebagai mitra. Dalam arti, dengan mempraktekkan prinsip mudharabah dan dengan mengkombinasikan berbagai unit produksi, proyek industri, perdagangan dan pertanian dalam kerangka perencanaan dapat diterapkan atas dasar prinsip tersebut. Pendapatan yang dihasilkan oleh usaha seperti itu dapat dibagi secara sebanding setelah dikurangi segala pengeluaran yang sah.

\section{Konsep Minat}

Sedangkan pengertian minat secara istilah sebagai suatu kondisi yang terjadi apabila seseorang melihat ciri-ciri atau arti sementara situasi yang dihubungkan dengan keinginan-keinginan atau kebutuhan-kebutuhannya sendiri.

Berdasarkan definisi tersebut dapatlah penulis kemukakan bahwa minat mengandung unsur-unsur sebagai berikut:

a. Minat adalah suatu gejala psikologis

b. Adanya pemusatan perhatian, perasaan dann pikiran dari subjek karena tertarik

c. Adanya perasaan senang terhadap objek yang menjadi sasaran

d. Adanya kemauan atau kecenderungan pada diri subjek untuk melakukan kegiatan guna mencapai tujuan. 


\section{Pengertian Bank Syari'ah}

Bank syariah menurut Undang-Undang Republik Indonesia Nomor 21 Tahun 2008 tentang perbankan syariah, bank syariah dan bank umum syariah adalah:

a. Perbankan syariah adalah segala sesuatu yang menyangkut tentang Bank Syariah dan Unit Usaha Syariah, mencakup kelembagaan, kegiatan usaha, serta cara dan proses dalam melaksanakan kegiatan usaha.

b. Bank syariah adalah Bank yang menjalankan kegiatan usahanya berdasarkan prinsip syariah dan menurut jenisnya terdiri atas Bank Umum Syariah dan Bank Perkreditan Rakyat Syariah.

c. Bank Umum Syariah adalah Bank Syariah yang dalam kegiatannya memberikan jasa dalam lalu lintas pembayaran. ${ }^{5}$

Bank Syariah sebagai bank yang dalam aktivitasnya, baik penghimpunan dana maupun dalam rangka penyaluran dananya memberikan dan menggunakan imbalan atas dasar prinsip syariah yaitu jual beli dan bagi hasil.

\section{Perbedaan Bank Islam dan Bank Konvensional}

Sistem perbankan Islam berbeda dengan sistem perbankan konvensional, karena sistem keungan dan perbankan Islam merupakan subsistem dari suatu ekonomi Islam yang cakupannya lebih luas. Karena itu, perbankan Islam tidak hanya dituntut untuk menghasilkan profit secara komersial, namun juga dituntut secara sungguh-sungguh menampilkan realisasi nilai-nilai syariah.

Di dalam perbankan konvensional terdapat kegiatan-kegiatan yang dilarang oleh syariat Islam, seperti menerima dan membayar bunga (riba), membiayai kegiatan produksi dan perdagangan barang-barang yang diharamkan seperti minuman keras (haram), kegiatan yang sangat dekat dengan gambling (maisir) untuk transaksitransaksi tertentu dalam foreign exchange dealing, serta highly and intented speculative transaction (gharar) dalam investment banking.

Berdasarkan prinsip utama itu, maka secara operasional terdapat perbedaanperbedaan yang substantif antara perbankan Islam dengan perbankan konvensional, seperti telihat pada Tabel 2.1. ${ }^{6}$ 
Tabel 2.1

Perbedaan Bank Islam Dan Bank Konvensional

\begin{tabular}{|c|c|c|}
\hline KETERANGAN & BANK ISLAM & $\begin{array}{c}\text { BANK } \\
\text { KONVENSIONAL }\end{array}$ \\
\hline $\begin{array}{c}\text { Akad dan Aspek } \\
\text { Legalitas }\end{array}$ & $\begin{array}{c}\text { Hukum Islam dan Hukum } \\
\text { Positif }\end{array}$ & Hukum Posistif \\
\hline Lembaga penyelesaian & BASYARNAS & BANI \\
\hline Struktur organisasi & $\begin{array}{c}\text { Ada Dewan Syariah } \\
\text { Nasional (DSN) dan Dewan } \\
\text { Pengawas Syariah (DPS) }\end{array}$ & $\begin{array}{c}\text { Tidak ada DSN dan } \\
\text { DPS }\end{array}$ \\
\hline Investasi & Halal & Halal dan haram \\
\hline Prinsip operasional & Bagi hasil, jual beli sewa & Perangkat bunga \\
\hline Tujuan & Profit dan falah oriented & Profit oriented \\
\hline Hubungan Nasabah & Kemitraan & Debitor dan Kreditor \\
\hline
\end{tabular}

Sumber: Bank dan Asuransi Islam di Indonesia

\section{Pengertian Tabungan Syari'ah}

Adapun yang dimaksud dengan tabungan syariah adalah tabungan yang dijalankan berdasarkan prinsip-prinsip syariah. Dalam hal ini, Dewan Syariah Nasional telah mengeluarkan fatwa yang menyatakan bahwa tabungan yang dibenarkan adalah yang berdasarkan prinsip wadi'ah dan mudharabah. ${ }^{7}$

\section{TabunganKu}

Pada awal 2010 lalu Presiden Susilo Bambang Yudhoyono mengeluarkan Gerakan Ayo Manabung lewat TabunganKu. Gerakan ini didukung oleh 70 bank umum dan bank syariah serta 910 Bank Perkreditan Rakyat/Syariah. Munculnya gerakan ini awalnya dipicu dari keprihatinan kalangan perbankan yang melihat menabung belum menjadi budaya rakyat Indonesia.

Saat ini lebih dari 138 juta penduduk usia dewasa yang produktif, hanya 58 juta saja yang memiliki tabungan, sisanya 80 juta belum tersentuh layanan perbankan.

Bahkan ada bank syariah yang membidik calon nasabah dari kalangan lembaga pendidikan, termasuk siswanya, mulai dari tingkat TK sampai SMA. Siswa sekolah merupakan salah satu sasaran yang tepat untuk diajak membuka rekening tabungan karena akan menanamkan kebiasaan menabung sejak dini. Apalagi fitur produk TabunganKu iB ini memang sengaja dibuat lebih menarik dibanding produk tabungan lainnya, karena bebas biaya administrasi dan setoran awalnya juga sangat ringan. ${ }^{8}$ 


\section{B. Hipotesis}

Menurut Good dan Scates menyatakan bahwa hipotesis adalah sebuah taksiran atau referensi yang dirumuskan serta diterima untuk sementara yang dapat menerangkan fakta atau kondisi yang diamati, dan digunakan sebagai petunjuk untuk langkah penelitian selanjutnya. Sedangkan menurut Kerlinger menyatakan hipotesis adalah pernyataan yang bersifat terkaan dari hubungan antara dua atau lebih variabel. ${ }^{9}$

Jadi hipotesis merupakan suatu jawaban sementara dan masih perlu diuji kebenarannya.

Hipotesis pertama:

$\boldsymbol{H}_{\boldsymbol{o}}=$ Diduga Strategi Pemasaran tidak berpengaruh Terhadap Minat Nasabah Memilih Produk Tabunganku

$\mathrm{H}_{\mathrm{a}}=$ Diduga Strategi Pemasaran berpengaruh Terhadap Minat Nasabah Memilih Produk Tabunganku

\section{METODE PENELITIAN}

\section{A. Ruang Lingkup Penelitian}

\section{Tempat dan waktu penelitian}

Penelitian ini dilakukan di Bank Muamalat Indonesia Cabang Serang, pada bulan Desember sampai akhir Desember 2013 penulis menganalisis pengaruh strategi pemasaran terhadap minat nasabah memilih produk Tabunganku.

\section{Metode Penelitian}

Metode adalah cara melakukan sesuatu dengan menggunakan fikiran secara seksama untuk mencapai tujuan, sedangkan penelitian adalah suatu kegiatan untuk mencari, mencatat, merumuskan dan menganalisa sampai menyusun laporan.

Penelitian ini menggunakan metode deskriptif analisis dengan dengan pendekatan kuantitatif. Metode deskriptif analisis ditujukan untuk menggambarkan bagaimana pengaruh strategi pemasaran terhadap minat nasabah memilih produk tabunganku.

\section{B. Teknik Pengumpulan Data}

\section{Populasi dan Sampel Penelitian}

Populasi adalah wilayah generalisasi yang terdiri atas objek atau subjek yang mempunyai kualitas dan karakteristik tentunya ditetapkan oleh peneliti untuk dipelajari kemudian ditarik kesimpulannya. Dari hasil wawancara dengan Customer Service Bank Muamalat Cabang Serang, jumlah seluruh nasabah tabunganku pada Muamalat Cabang Serang dari bulan Mei 2010 sampai Oktober 2013 berjumlah 578 orang.

Sebagian anggota populasi yang dipilih dengan menggunakan prosedur tertentu sehingga diharapkan mewakili populasinya. ${ }^{10}$ Prosedur yang digunakan dalam pemilihan sampel adalah pengambilan sampel dengan cara purposive sampling 
yaitu pengambilan sampel yang dipilih dengan cermat sehingga relevan dengan rangcangan penelitian. ${ }^{11}$

Sampel adalah sebagian atau wakil populasi yang diteliti. ${ }^{12}$ Dalam penelitian ini Radiani dan Bungin memberikan gambaran rumus untuk perhitungan besaran sampel, yang karena populasi sukar digambarkan, sebagai berikut ${ }^{13}$

$$
n=\frac{\mathrm{N}}{\mathrm{N}(\mathrm{d})+1}
$$

Keterangan :

$\mathrm{n}$ : Jumlah sampel yang dicari

$\mathrm{N}$ : Jumlah populasi

d : persen kelonggaran dalam kesalahan (ditentukan dalam contoh ini besar $90 \%$ atau $\mathrm{d}=0,15$ )

Populasi yang digunakan penulis adalah nasabah yang menggunakan tabunganku. Dimana berdasarkan data yang diperoleh ada 578 orang berbentuk:

$$
n=\frac{578}{578(0,15)^{2}+1}=41
$$

Berdasarkan perhitungan tersebut diatas, maka penulis memutuskan untuk mengambil 41 orang responden.

\section{Variabel Penelitian}

Variabel penelitian didefinisikan sebagai atribut dari sekelompok objek yang diteliti mempunyai variasi antara satu dengan yang lainnya dalam kelompok tertentu. ${ }^{14}$

\section{Jenis dan Sumber Data}

Pengumpulan data dapat dilakukan menggunakan dua sumber data, yaitu sumber data primer dan sekunder.

\section{Metode Pengumpulan dan Pengukuran Data}

a. Pengumpulan Data

i. Penelitian pustaka (Library Research) adalah penelitian yang dilakukan dengan cara mengumpulkan beberapa landasan teori dari para ahli yang bersumber dari berbagai literatur, buku, referensi, dokumen dan sebagainya yang berkaitan dengan objek pembahasan sebagai bahan analisis.

ii. Penelitian lapang (Field Research) adalah penelitian yang bertujuan untuk memperoleh data sehubungan dengan penulisan ini, ${ }^{15}$ dengan jalan:

a. Metode Observasi

Metode ini digunakan dengan cara langsung datang ke lokasi penelitian yaitu Bank Muamalat Indonesia Cabang Serang. 
b. Wawancara (Interview), yaitu pengumpulan informasi dengan cara melakukan tanya jawab dengan Manager Marketing, customer service Bank Muamalat Cabang Serang tentang hal hal yang berhubungan dengan Bank Muamalat dan produk-produknya, dan para nasabah yang menggunakan produk tabunganku di Bank Muamalat Cabang Serang.

c. Metode Kuesioner (Angket)

Merupakan sejumlah pertanyaan tetulis yang digunakan untuk memperoleh informasi dari responden dalam arti laporan tentang pribadinya, atau hal-hal yang ia ketahui. Angket yang digunakan adalah pilihan untuk memudahkan bagi responden dalam memberikan jawaban, karena alternatif jawaban sudah disediakan dan hanya membutuhkan waktu yang lebih singkat untuk menjawabnya.

Skala pengukuran dalam penyusunan kuisioner adalah skala likert, yaitu skala yang berisi tingkat jawaban yang merupakan skala sejenis ordinal sebagai berikut: ${ }^{16}$

Skala ini mengukur ordinal karena hanya dapat membuat rangking tetapi tidak dapat diketahui beberapa kali satu responden lebih baik atau lebih buruk dari responden lainnya didalam nilai nilai skala. Contoh skala likert: ${ }^{17}$

\section{Keterangan:}

Tabel 3.1

Pedoman Skala Likert

\begin{tabular}{|c|l|c|}
\hline NO & \multicolumn{1}{|c|}{ KETERANGAN } & SKOR \\
\hline 1 & Sangat Setuju (SS) & 5 \\
\hline 2 & Setuju (S) & 4 \\
\hline 3 & Ragu (R) & 3 \\
\hline 4 & Tidak Setuju (TS) & 2 \\
\hline 5 & Sangat Tidak Setuju (STS) & 1 \\
\hline
\end{tabular}

Sumber: Konsep Dasar Riset Pemasaran \& Perilaku Konsumen

\section{Teknik Analisis Data}

Adapun teknik analisis data yang digunakan untuk pembahasan dalam penelitian ini adalah sebagai berikut:

1. Analisis deskriptif

2. Uji Validasi dan Reabilitas Data

3. Analisis Koefisien Korelasi

4. Pengujian Hipotesis

a. Uji t

b. Koefisien Determinasi (R Square atau $R^{2}$ ) 


\section{Pembahasan}

\section{A. Gambaran Umum Penelitian}

\section{Sejarah Berdirinya Bank Muamalat}

PT. Bank Muamalat Indonesia Tbk didirikan pada tanggal 24 Rabiul Tsani $1412 \mathrm{H}$. Atau pada tanggal 1 Nopember 1991 yang diprakarsai oleh beberapa tokoh Majelis Ulama Indonesia (MUI) dan beberapa muslim yang kemudian tergabung kedalam Ikatan Cendekiawan Muslim Indonesia (ICMI) serta pemerintah. Bank Muamalat Indonesia mulai beroperasi pada tanggal 27 Syawal $1412 \mathrm{H}$, atau pada tanggal 1 Mei 1992 M. Dengan dukungan tokoh dan pemimpin muslim serta beberapa pengusaha muslim. Pendirinya juga mendapat dukungan masyarakat berupa komitmen pembelian saham senilai Rp. 84 Miliyar pada saat penandatanganan pendirian perseroan. Selanjutnya dalam acara silaturahmi pendirian di Istana Bogor diperoleh tambahan modal dari masyarakat jawa barat sebesar 22 Miliyar sehingga menjadi 106 Miliyar sebagai wujud dukungan.

Pada tanggal 27 Oktober 1994 hanya dua tahun setelah didirikan, Bank Muamalat berhasil menyandang predikat Bank Devisa. Pengakuan ini semakin memperkokoh posisinya sebagai bank syari'ah pertama dan terkemuka di Indonesia dengan beragam jasa dan produk yang harus dikembangkan.

Krisis moneter pada tahun 1997 sampai dengan 1998 telah memporakporandakan sebagian besar perekonomian Asia Tenggara. Sektor perbankan terbelit Negative Spead dan bencana kredit macet. Akibatnya sejumlah bank mengalami kondisi terburuk dalam Pengawasan Badan Penyehatan Perbankan Nasional (BPPN) dan terpaksa harus memperoleh rekapitulasi pemerintah.

\section{B. Gambaran Umum Responden}

1) Responden Berdasarkan Jenis Kelamin

Gambar 4.1 :

\section{Responden berdasarkan Jenis Kelamin}

\section{Jenis kelamin}

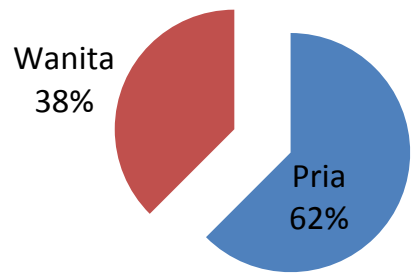

Sumber: Data primer yang diolah oleh peneliti

Berdasarkan data yang diperoleh dari 41 responden, sebagian besar responden berjenis kelamin pria, yaitu sebanyak 25 orang atau sebesar $62 \%$, dan sebanyak 16 
orang atau sebesar $38 \%$ berjenis kelamin wanita. Jadi dapat dikatakan bahwa mayoritas nasabah tabunganku di Bank Muamalat Indonesia Cabang Serang didominasi oleh berjenis kelamin pria.

2) Responden Berdasarkan Usia

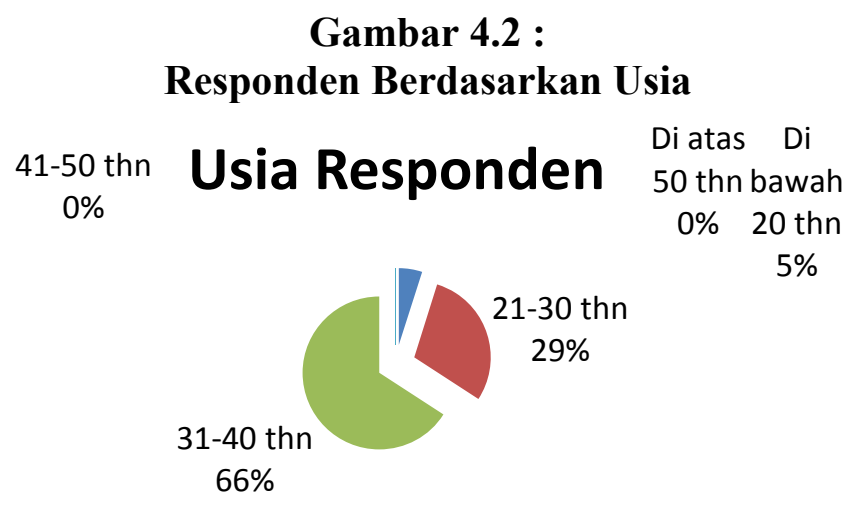

Sumber: Data primer yang diolah oleh peneliti

Berdasarkan data yang dikumpulkan dapat dilihat bahwa sebanyak 2 orang atau sebesar $5 \%$ responden berusia $<20$ tahun, 12 orang atau sebesar $29 \%$ berusia 21 30 tahun, 27 orang atau sebesar $66 \%$ berusia 31-40 tahun, dengan demikian jumlah responden terbanyak berada pada usia dewasa.

3) Responden Berdasarkan Tingkat Pendidikan

Gambar 4.3 :

Responden Berdasarkan Tingkat Pendidikan

Tingkat pendidikan

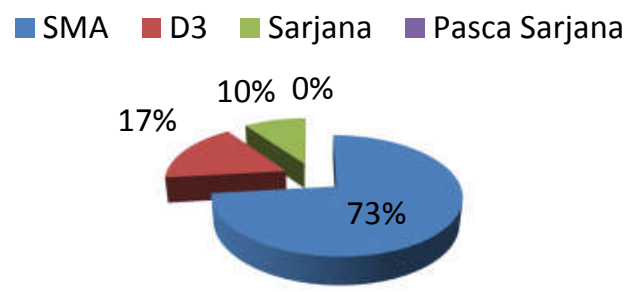

Sumber: Data primer yang diolah oleh peneliti

Dari 41 orang responden yang memiliki pendidikan terakhir SMA sebanyak 30 orang atau sebesar $73 \%, 7$ orang atau sebesar $17 \%$ berpendidikan terakhir Diploma, 4 orang atau sebesar $10 \%$ berpendidikan terakhir sarjana. Jadi dapat disimpulkan bahwa mayoritas nasabah tabunganku memiliki pendidikan SMA. 
4) Responden Berdasarkan Jenis Pekerjaan

Gambar : 4.4

Responden Berdasarkan Jenis Pekerjaan

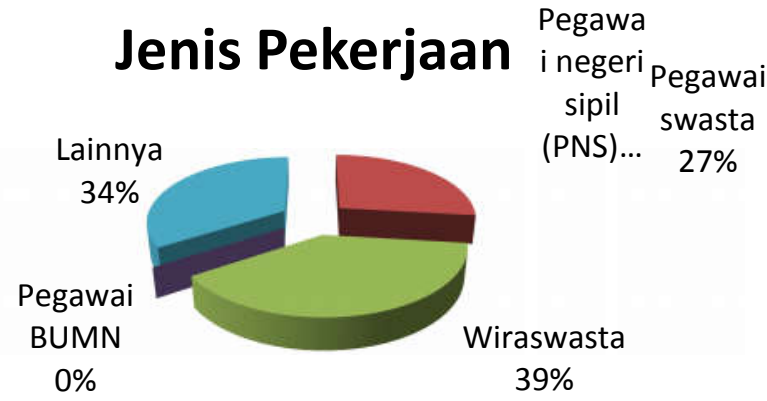

Sumber: Data primer yang diolah oleh peneliti

\section{Pembahasan Hasil Penelitian}

1. Analisis Deskriptif

Tabel 4.1

Analisis Deskriptif

Descriptive Statistics

\begin{tabular}{|c|c|c|c|}
\hline & $\mathrm{N}$ & Mean & $\begin{array}{c}\text { Std. } \\
\text { Deviation }\end{array}$ \\
\hline Strategi Pemasaran & 41 & 58.90 & 5.171 \\
TabunganKU & 41 & 58.93 & 3.958 \\
Valid N (listwise) & 41 & & \\
\hline
\end{tabular}

Sumber: Data Primer diolah dengan SPSS 16.0

Hasil deskriptif variabel strategi pemasaran (X) dalam tabel 4.1 Descriptive Statistics dijelaskan bahwa terdapat jumlah kasus $(\mathrm{N})=41$ responden yang mengisi angket dengan rata-rata (mean) sebesar 59.90 dan simpangan baku (standar deviasi) $=5,171$, variabel tabunganku $(\mathrm{Y})$, jumlah kasus $(\mathrm{N})=41$ responden yang mengisi angket dengan rata-rata (mean) sebesar 58,93 dan simpangan baku (standar deviasi) $=3,958$.

2. Uji Validasi Dan Reabilitas Data

Hipotesis: $r_{\text {hitung }}>r_{\text {tabel }}$ berarti data Valid dan Reliabilitas

Uji validitas digunakan untuk mengukur sah atau valid tidaknya suatu kuesioner. Suatu kuesioner dikatakan valid jika pertanyaan pada kuesioner 
mampu untuk mengungkapkan sesuatu yang akan di ukur oleh kuesioner tersebut.

Dalam penelitian ini, $r_{\text {hitung }}$ diperoleh dari rumus degree of freedom $(d f)=\mathrm{n}-\mathrm{k}$, dimana (n) merupakan jumlah sempel dan (k) merupakan jumlah variabel independen. Jumlah sampel (n) dalam penelitian ini $=41$ dan besarnya df yang dapat dihitung $41-1=40$ dan $\alpha=0,05$ (2-tailed). Untuk mengetahui nilai $r_{\text {tabel }}$, maka lihat dalam lampiran tabel $r$ (pearson Product Moment). Dasar pengambilan keputusan:

- Jika $r_{\text {hitung }} \geq r_{\text {tabel }}$, maka item kuesioner valid

- Jika $r_{\text {hitung }} \leq r_{\text {tabel }}$, maka item kuesioner tidak valid

Dengan hasil analisis menggunakan SPSS ver 16.0 maka diketahui bahwa nilai validitas dan reabilitas adalah sebagai berikut:

Tabel 4.2

Uji Validasi

Item-Total Statistics

\begin{tabular}{|l|r|r|r|r|}
\hline & $\begin{array}{c}\text { Scale Mean if } \\
\text { Item Deleted }\end{array}$ & $\begin{array}{c}\text { Scale } \\
\text { Variance if } \\
\text { Item Deleted }\end{array}$ & $\begin{array}{c}\text { Corrected } \\
\text { Item-Total } \\
\text { Correlation }\end{array}$ & $\begin{array}{c}\text { Cronbach's } \\
\text { Alpha if Item } \\
\text { Deleted }\end{array}$ \\
\hline Strategi Pemasaran & 58.93 & 15.670 & .572 &.${ }^{\mathrm{a}}$ \\
TabunganKU & 58.90 & 26.740 & .572 &. \\
\hline
\end{tabular}

a. The value is negative due to a negative average covariance among items. This violates reliability model assumptions. You may want to check item codings.

\section{Sumber: Data diolah menggunakan program SPSS 16.0}

Dari hasil tersebut kita bisa mengetahui bahwa nilai $r$ hitung validitas variabel $\mathrm{X}$ dan variabel $\mathrm{Y}$ yaitu dalam kasus ini Strategi Pemasaran dan Tabunganku berada pada kolom Corrected Item-Total Correlation. Dan nilainya adalah 0,572. Sedangkan nilai $r_{\text {sabel }}$ yaitu 0,304. Maka dengan itu bahwa data ini valid. 
Tabel 4.3

Reabilitas Data

Reliability Statistics
\begin{tabular}{|r|r|}
\hline $\begin{array}{c}\text { Cronbach's } \\
\text { Alpha }\end{array}$ & N of Items \\
\hline .712 & 2 \\
\hline
\end{tabular}

Sumber: Data diolah menggunakan program SPSS 16.0

Tabel 4.4

Reliability Statistics

\begin{tabular}{|c|c|c|c|}
\hline No. Butir pertanyaan & $\begin{array}{c}\text { Cronbach's } \\
\text { Alpha }\end{array}$ & R Standar & Keterangan \\
\hline Strategi Pemasaran (X) & 0,712 & 0,60 & Reliabel \\
Tabunganku (Y) & 0,712 & 0,60 & Reliabel \\
\hline
\end{tabular}

Sumber: Data diolah menggunakan program SPSS 16.0

Dari tabel 4.4 di atas, didapatkan koefisien Alpha Cronbach's untuk variabel X (Strategi Pemasaran) sebesar 0,712, selanjutnya variabel Y (Tabunganku) sebesar 0,712, sehingga dari pengujian ini dapat disimpulkan bahwa instrument yang digunakan dalam penelitian ini sudah memiliki kehandalan (reliabilitas).

3. Analisis Koefisien Korelasi

Tabel: 4.5

Koefisien korelasi

\begin{tabular}{|l|r|r|r|r|r|}
\hline \multicolumn{7}{|c|}{ Model Summary $^{\mathbf{b}}$} \\
\hline Model & $\mathrm{R}$ & R Square & $\begin{array}{c}\text { Adjusted R } \\
\text { Square }\end{array}$ & $\begin{array}{l}\text { Std. Error of } \\
\text { the Estimate }\end{array}$ & $\begin{array}{l}\text { Durbin- } \\
\text { Watson }\end{array}$ \\
\hline 1 & $.572^{\mathrm{a}}$ & .328 & .310 & 3.287 & 2.273 \\
\hline
\end{tabular}

a. Predictors: (Constant), Strategi Pemasaran

b. Dependent Variable: TabunganKU 
Sumber: Data diolah menggunakan program SPSS 16.0

Berdasarkan hasil analisa dengan menggunakan SPSS diperoleh koefisien korelasi $\mathrm{r}$ adalah 0,572 menyatakan bahwa pengaruh variabel independen (Strategi pemasaran) terhadap variabel dependen (minat nasabah memilih produk tabunganku) sebesar $57,2 \%$ yang artinya strategi pemasaran mempunyai pengaruh yang sedang antara kedua variabel karena berada di rentang 0.40-0.599 ( korelasi sedang) dan sisanya $(100 \%-57,2=42,8 \%)$ dipengaruhi oleh variabel lain yang tidak dibahas dalam penelitian ini. Maka dapat disimpulkan hubungan yang signifikan. ${ }^{18}$

4. Pengujian hipotesis

a. Uji t

Hipotesis:

Ho $=1=$ Strategi pemasaran tidak berpengaruh terhadap minat nasabah memilih produk tabunganku

Ha $\neq 0=$ Strategi pemasaran berpengaruh terhadap minat nasabah memilih produk tabunganku.

Tabel: $\mathbf{4 . 6}$

Hasil uji t

Coefficients $^{\mathrm{a}}$

\begin{tabular}{|c|c|c|c|c|c|}
\hline \multirow[b]{2}{*}{ Model } & \multicolumn{2}{|c|}{$\begin{array}{l}\text { Unstandardized } \\
\text { Coefficients }\end{array}$} & $\begin{array}{l}\text { Standardized } \\
\text { Coefficients }\end{array}$ & \multirow[b]{2}{*}{$\mathrm{T}$} & \multirow[b]{2}{*}{ Sig. } \\
\hline & B & Std. Error & Beta & & \\
\hline (Constant) & 33.116 & 5.942 & & 5.573 & .000 \\
\hline Strategi Pemasaran & .438 & .101 & .572 & 4.360 & .000 \\
\hline
\end{tabular}

a. Dependent Variable: TabunganKU

Sumber: Data primer diolah dengan SPSS ver 16.0

Analisis dengan SPSS terlihat bahwa thitung 4,360 dengan menggunakan tingkat signifikan $\alpha=5 \%$ dan derajat kebebasan $(\mathrm{df})=41-1$ $1=39$, maka diketahui $t_{\text {tabel }}=1,70$.

Dari hasil tersebut menunjukkan bahwa $t_{\text {hitung }}$ lebih besar dari $t_{\text {tabel }}$ yaitu sebesar $(4,360>1,70)$. Hal ini berarti bahwa $H_{0}$ ditolak dan $\mathrm{H}_{a}$ diterima, artinya bahwa ada pengaruh antara strategi pemasaran terhadap minat nasabah memilih produk tabunganku.

b. Koefisien Determinasi 
Dari hasil analisis menggunakan SPSS 16.0 diketahui koefisien korelasi adalah sebagai berikut:

Tabel: 4.7

\section{Hasil Koefiesien Determinasi}

Model Summary

\begin{tabular}{|l|l|r|r|r|}
\hline Model & R & R Square & $\begin{array}{c}\text { Adjusted R } \\
\text { Square }\end{array}$ & $\begin{array}{l}\text { Std. Error of } \\
\text { the Estimate }\end{array}$ \\
\hline 1 & $.572^{\mathrm{a}}$ & .328 & .310 & 3.287 \\
\hline
\end{tabular}

a. Predictors: (Constant), Strategi Pemasaran

b. Dependent Variable: Tabunganku

Sumber: Data diolah menggunakan program SPSS 16.0

Koefisien determinasi merupakan ukuran yang mengukur presentasi variabel angket dapat dijelaskan oleh garis regresi linier. Pengukuran ini digunakan untuk mengukur seberapa besar perubahan nilai $Y$ dapat dijelaskan oleh variabel X. dari hasil analisis diperoleh $R^{2}=0,328$ artinya bahwa $32,8 \%$ perubahan tabunganku dipengaruhi oleh strategi pemasaran, dan sisanya $(100 \%-32,8 \%=67,2 \%)$ dipengaruhi oleh variabel lain yang tidak dibahas dalam penelitian ini.

\section{Penutup}

\section{A. Kesimpulan dan Rekomendasi}

Berdasarkan hasil penelitian dan pembahasan yang telah dipaparkan pada bab sebelumnya, maka penulis dapat mengambil kesimpulan sebagai jawaban dari perumusan masalah.

1. Alasan nasabah memilih produk tabunganku adalah dari pemenuhan produk (product), penetapan harga (price), pengiriman barang (place), dan mempromosikan barang (promotion). Keragaman dan manfaat produk tabungan untuk perorangan dengan persyaratan mudah dan ringan yang terjangkau bagi semua kalangan masyarakat serta bebas biaya administrasi. Strategis dan mudah dijangkau, kelengkapan dengan menggunakan sarana dan prasana yang ada.

2. Bahwa strategi pemasaran berpengaruh signifikan terhadap minat nasabah memilih produk tabunganku. Dari hasil statistik menggunakan SPSS ver 16.00 hal ini dapat dilihat dari angka korelasi sebesar $57 \%$ yang artinya hubungan kedua variabel adalah sedang. Dari hasil tersebut menunjukkan bahwa $t_{\text {hitung }}$ lebih besar dari $t_{\text {tabel }}$ yaitu sebesar $(4,360>1,70)$. Hal ini berarti bahwa $H_{0}$ ditolak dan $H_{a}$ diterima, artinya bahwa ada pengaruh antara strategi pemasaran terhadap minat nasabah memilih produk 
tabunganku. Nilai R sebesar 0.572 yang artinya pengaruh strategi pemasaran terhadap minat nasabah memilih produk tabunganku sedang. Nilai $R^{2}=0,328$ artinya bahwa 32,8\% perubahan tabunganku dipengaruhi oleh strategi pemasaran, dan sisanya $(100 \%-32,8 \%=67,2 \%)$ dipengaruhi oleh variabel lain yang tidak dibahas dalam penelitian ini.

\section{Catatan Akhir:}

1 http://kumpulan-artikel2.blogspot.com/2012/12/tabungan-muamalat-untuk-pelajar.html. Di unduh pada hari Senin, 28-10-2013 pkl 14:22.

${ }^{2} \mathrm{http} / / /$ id.wikipedia.org/wiki/Pemasaran. Di unduh pada hari selasa 22-10-2013 pkl 11:43 wib

${ }^{3}$ Sofjan Assuari, op.cit,.h.168.

${ }_{5}^{4}$ Syamil Qur'an, Departemen Agama RI, al qur'an dan terjemahnya,op.cit,.h.554

${ }^{5}$ Undang-undang Republik Indonesia Nomor 21 Tahun 2008 tentang perbankan syariah (Rika Rizki Yuliani, Pengaruh Non Performing Financing Terhadap Pendapatan Margin Murabahah Perbankan Syariah, Skripsi, Program Sarjana IAIN “Sultan Maulana Hasanuddin” Banten, Serang: 2012), p.16

${ }^{6}$ Wirdyaningsih, op.cit,.h.39.

${ }^{7}$ Adiwarman A Karim, op.cit,.h.271.

8 http://ib-bloggercompetition.kompasiana.com/2011/01/06/tabunganku-ib-masuk-sekolah-masadepan-bangsa-cerah-330952.html, di unduh pada hari Rabu, 26 Maret 2014. Pukul 15:06 WIB

${ }^{9}$ Moh. Nazir, Metode Penelitian, Jakarta: Ghalia Indonesia, 2003, h.151.

${ }^{10}$ Sugiarto, et.all,.Teknik Sampling, Jakarta: Gramedia Pustaka Utama, 2003, h.2.

${ }^{11}$ Muhammad, Metode Penelitian Ekonomi Islam Pendekatan Kuantitatif, Jakarta: Raja Grafindo Persada, 2008, h.175

${ }^{12}$ Ibid,.h.62

${ }^{13}$ Tukiran Taniredja dan Hidayati Mustafidah, Penelitian Kuantitatif sebuah Pengantar, Bandung: Alfabeta, 2011, h.38.

${ }_{15}^{14}$ Sugiyono, op.cit,.h.58.

${ }^{15}$ Sofian Siregar, Statistik Deskriptif Untuk Penelitian, Jakarta: Rajawali Pers, 2010, h.124.

${ }_{17}$ Muhammad, op.cit,.h.154.

${ }^{17}$ Danang Sunyoto, op.cit,.h.93.

18 Riduawan,. Et,.all, Cara Mudah Belajar SPSS 17.0 dan Aplikasi Statistik Penelitian, Bandung: Alfabeta, 2013, h.79.

\section{DAFTAR PUSTAKA}

Agama, RI Departemen, Alqur'an Dan Terjemahnya, (Jakarta: CV Darus sunah, 2002), p.549

Ascarya, Akad Dan Produk Bank Syariah, Jakarta: PT Rajagrafindo Persada, 2007 
Assuari, Sofjan, Manajemen Pemasaran Dasar, Konsep \& Strategi, Cetakan Ke 11 Jakarta: Raja Grafindo Persada, 2011

E. Vogel, Frank, and Hayes, Samuel L. Hukum Keuangan Islam, Konsep Teori Dan Praktek, Cetakan I, Bandung: Nusamedia, 2007

Edwin Nasution, Mustafa, et al., Pengenalan Ekslusif Ekonomi Islam, Jakarta: Kencana Prenada Media Group, 2006

Hergawati, Heni, Pengaruh Strategi Pemasaran Perbankan Syariah Terhadap Peningkatan Jumlah Nasabah. Serang, IAIN "Sultan Maulana Hasanuddin" Banten: 2012

Karim, Adiwarman, Bank Islam Analisis fiqih dan Keungan Edisi Dua, Jakarta: PT Raja Grafindo Persada, 2004

Kasmir, Bank dan Lembaga Keuangan Lainnya, Jakarta: PT Raja Grafindo Persada, 2008

Kotler, Philip, and Lane Keller, Kevin, Manajemen Pemasaran, edisi ketiga belas, Jakarta : Erlangga, 2009

Lamri, Ujang, Strategi Bank BRI Syariah Cabang Cilegon Dalam memberdayakan Usaha Kecil Menengah (UKM) di Kota Cilegon, Serang, IAIN "Sultan Maulana Hasanuddin" Banten: 2012

Muhammad, Metode Penelitian Ekonomi Islam Pendekatan Kuantitatif, Jakarta: Raja Grafindo Persada, 2008

Mutmainah, Lilis, Pengaruh Strategi Pemasaran Terhadap Minat Mengikuti Program Asuransi Pendidikan (Mitra Iqra), Serang: IAIN "Sultan Maulana Hasanuddin" Banten, 2011

Nazir, Moh. Metode Penelitian, Jakarta: Ghalia Indonesia, 2003

Nengsih, Pengaruh Tabungan Mudharabah Terhadap Biaya Operasional Bank Syariah. Serang, IAIN “Sultan Maulana Hasanuddin” Banten: 2011

Nisa, Khoirun, Pengaruh Strategi Pemasaran Terhadap Peningkatan Jumlah Nasabah dalam Produk Pembiayaan Bank Syariah. Serang, IAIN "Sultan Maulana Hasanuddin" Banten: 2011 
Prabu Mangkunegara, Anwar, Prilaku Konsumen, cetakan ke empat, Bandung: PT Refika Aditama, 2002

Riduwan,. et,.all, Cara Mudah Belajar SPSS 17.0 dan Aplikasi Statistik Penelitian, Alfabeta, Bandung: 2013

Rizki Yuliani, Rika, Pengaruh Non Performing Financing Terhadap Pendapatan Margin Murabahah Perbankan Syariah, Serang: IAIN "Sultan Maulana Hasanuddin" Banten, 2012

Siregar, Sofian, Statistik Deskriptif Untuk Penelitian, Jakarta: Rajawali Pers, 2010

Slamet, Belajar \& Faktor-Faktor yang Mempengaruhinya, Jakarta: Rineka Cipta, 2010

Sobur Alex, Psikologi Umum, Bandung: Pustaka Setia, 2003

Soemitro, Andri, Bank \& Lembaga Keungan Syari'ah, Edisi Pertama Cetakan Kedua Jakarta: Kencana Prenada Media Group, 2010

Sonyoto, Danang Konsep Dasar Riset Pemasaran \& Perilaku Konsumen, Cetakan Pertama, Jakarta: CAPS, 2012

Sugiarto, et.all,. Teknik Sampling, Jakarta: Gramedia Pustaka Utama, 2003

Sugiyono, Statistik Untuk Penelitian Cetakan Ke 20, Jakarta: Alfabeta, 2012

Sujianto, Agus Eko, Aplikasi Statistik dengan SPSS,ver 16.00, Jakarta: Prestasi Pustakarya, 2009

Syari'ah dan Ekonomi Islam IAIN "Sultan Maulana Hasanuddin" Banten, Serang: fseipress, 2010

Taniredja, Tukiran dan Mustafidah, Hidayati, Penelitian Kuantitatif Sebuah Pengantar, Bandung: Alfabeta, 2011

Wirdyaningsih, et.all,. Bank Dan Asuransi Islam Di Indonesia, Edisi Pertama Cetakan Kedua, Jakarta: Kencana Prenada Media, 2006 
http://aprizal27.wordpress.com/2011/10/20/tabungan-syariah/, di unduh pada hari senin, 21-10-2013 pkl 16:56 wib

http://co2.web.id/skripsi-faktor-faktor-yang-mempengaruhi-minat-nasabah-terhadapproduk-tabungan-ib-plus.html. Di unduh pada hari senin, 21-10-2013 pkl 13:51 wib

http://id.wikipedia.org/wiki/Pemasaran. Di unduh pada hari selasa 22-10-2013 pkl 11:43 wib

http://kumpulan-artikel2.blogspot.com/2012/12/tabungan-muamalat-untukpelajar.html. Di unduh pada hari Senin, 28-10-2013 pkl 14:22

http://majalah.pengusahamuslim.com/pemasaran-dalam-perspektifislam/\#sthash.MViLsboO.dpuf, di unduh pada hari selasa, 22-10-2013 pk1 11:31 wib

http://ib-bloggercompetition.kompasiana.com/2011/01/06/tabunganku-ib-masuksekolah-masa-depan-bangsa-cerah-330952.html,

http://ancasindo.wordpress.com/2012/02/04/nasabah-muamalat-di-kti-50-nonmuslim/.

http://teorionline.wordpress.com/2010/01/24/uji-validitas-dan-reliabilitas/ di unduh pada hari Selasa, 22-10-2013 pkl 22:24 wib

http://www.dompetpintar.com/product/p1 kz/keuangan/ di unduh pada hari selasa, 2210-2013 pkl 13:39

http://www.muamalatbank.com/home/produk/tabunganku, di unduh pada hari selasa, 29-10-2013, pkl 18:43

http://www.pendidikanekonomi.com/2013/02/strategi-pemasaran.html. Di unduh pada hari selasa, 22-10-2013, pkl 11.45 wib

http://www.referensimakalah.com/2013/02/pengertian-bank-syariah.html, di unduh pada hari Senin, 21-10-2013 pkl 16:04 Wib 
http://www.syariahmandiri.co.id/category/edukasi-syariah/islamic-knowledge/.

Di unduh pada hari Senin, 21-10-2-13 pkl 14:07 wib

http://www.syariahmandiri.co.id/category/edukasi-syariah/islamic-knowledge/ Di unduh pada hari Senin, 21-10-2013 pkl 14:32 wib.

Laila Fitriani, alumni Jurusan Ekonomi Syariah Fakultas Syari'ah dan Ekonomi Islam IAIN Sultan Maulana Hasanuddin Banten

Asti Aini, dosen pada Fakultas Syari'ah dan Ekonomi Islam IAIN Sultan Maulana Hasanuddin Banten 